\title{
遊星歯車装置太陽軸の異常振動*
}

\author{
矢 鍋 重 夫*1, 吉 野 正 信*2, 山 岸信 雄*3
}

\section{Abnormal Vibration of Sun Gear Shaft in Planetary Gear Train}

\author{
Shigeo YANABE, Masanobu YOSHINO, Nobuo YAMAGISHI
}

\begin{abstract}
In a rotational system composed of a motor, star-type planetary gear increaser and dynamometer, a rotating shaft with a sun gear, which is supported by three planet gears through backlash, shows abnormal lateral vibration above a certain rotational speed during load operation. The value of the frequency of the vibration is three times that of the internal gear speed. The onset speed and amplitude of the vibration are strongly affected by the load torque. Effects of the number of planet gears, torsional stiffness of coupling and mass of the shaft on the lateral and torsional vibration of the system were experimentally investigated. Natural frequencies of the system and selfcentering loci of the shaft were also measured. The results show that the abnormal lateral vibration occurs when the rotational system generates torsional resonance and the gear teeth separate. Separation of the teeth is strongly influenced by the load torque.
\end{abstract}

Key Words: Vibration of Rotating Body, Nonlinear Vibration, Gear, Planetary Gear Train, Torsional Vibration, Abnormal Lateral Vibration, Load Torque, Backlash

\section{1. 緒言}

回転機械は，歯車装置などガタのある機械要素を含 むことが多い。こうした回転機械は，伝達トルクが小 さい場合または伝達トルクが変化する場合にさまざま な振動を発生することが経験的に知られている。しか しながら，実機で遭遇するこうしたトルク依存性のあ る振動について，トルクの大きさがどのような形でロ ータの振動(曲げあるいは横振動)に影響を及ぼすかと いうメカニズムはあまり解明されていないように思わ れる.本研究では，1段スタ一形遊星歯車増速機をガ タをもつ要素とし，これに可変速モータおよびダイナ モメータを結合した回転軸系を用いて実験を行った. 本装置を軽負荷で增速運転すると, 太陽軸(一端に太 陽歯車を有し，他端でダイナモに接続する剛性軸)は, ある回転速度以上で内歯車回転速度の 3 倍の振動数を もつ, 再現性のある大きな振幅の横振動 (以下, 異常振 動と呼ぶ)を発生する.この振動発生回転速度および振

* 平成 6 年 3 月 31 日 第 71 期定期総会講演会において講演, 原稿受付 平成 6 年 5 月 9 日.

*1 正員, 長岡技術科学大学（ 940-21 長岡市上富岡町 16031).

*A 正員, 長岡工業高等専門学校 ( 940 長岡市西片員町 888).

*3 新潟コンバータ (秼) ( 151 東京都涉谷区千駄ケ谷 5-27-9).
幅は顕著なトルク依存性を示した。そこで, 負荷トル ク, 遊星歯車の個数, 太陽軸の質量, モー夕側軸継手 のねじり剛性を変化させて, 增減速運転時における太 陽軸の水平・鉛直方向横振動および回転軸系のねじり 振動を実測し, 本振動の特徵を明らかにした.さらに 打撃実験を行い系の固有振動数を把握するとともに, ガタ支持された太陽軸のセルフセンタリング過程と異 常振動時の軸心軌跡を測定して, 両者の関連を明らか にし, 本振動の発生機構について考察したので以下に 報告する。

\section{2. 実験装置および実験方法}

図 1 に実験装置の概略, 図 2 に 1 段ス夕一形遊星歯 車増速機系 (遊星歯車は公転しない)の詳細, 表 1 に歯 車の主要仕様をそれぞれ示す．実験装置は可変速モ一 夕，遊星歯車増速機，ダイナモメー夕，およびこれら を結合する軸継手から成る，遊星歯車装置は，荷重等 配用の弾性ピンで支えられた 3 個の遊星歯車をもち, 速比 9.83 で, 強制潤滑されている. 横振動が問題とな る太陽軸は, 直径約 $21 \mathrm{~mm}$ 長さ $185 \mathrm{~mm}$ の剛性軸で, 一端を 3 個の遊星歯車, 他端をスプライン形またはダ イアフラム形軸継手で支えられており，軸受をもたな い. 各歯車は表 1 に示すように, モジュール 1.5, 圧力 


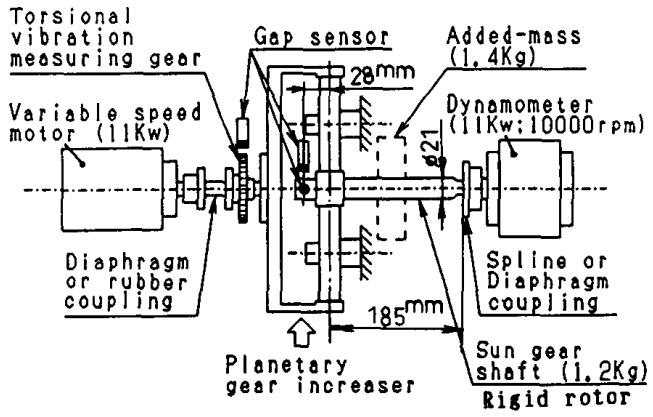

図 1 実験装置概略

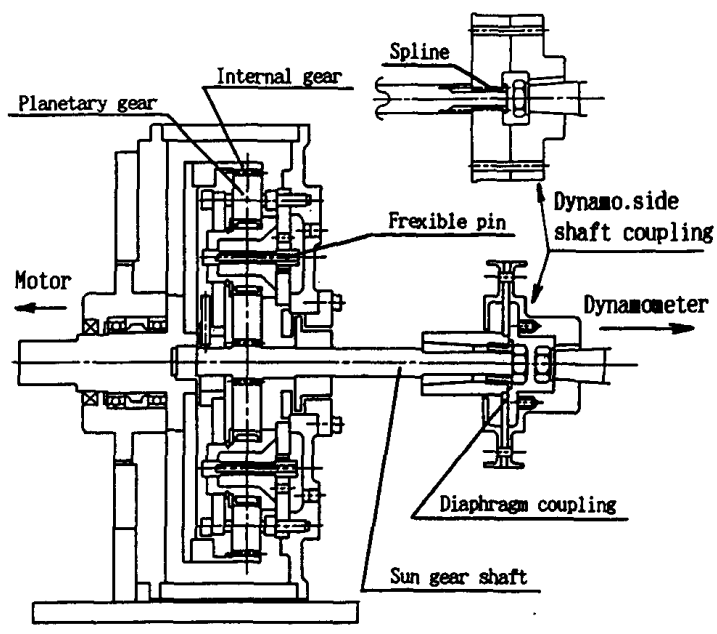

図 2 遊星歯車装置詳細

角 $20^{\circ}$ の平歯車で切削仕上げ品である.

太陽軸の水平および鉛直方向の横振動は, 遊星歯車 装置内に取付けた渦電流式の非接触式変位計で測定す る.ねじり振動は, 内歯車軸に取付けた計測用平歯車 （歯数 120）からのパルスの進み遅れを高速角変位計で 測定し，これを角度換算 (1 回転を $360^{\circ}$ として)し，振 幅の大きさとして表示した．組立時の実験装置のアラ イメント,ピックアップの取付け等には十分な注意を 払った。

実験は，一定負荷トルクの条件で回転速度を増減し た場合，および一定回転速度で負荷トルクを増減した 場合について，太陽軸の横振動および内歯車軸のねじ り振動を測定し，周波数分析を行った。実験装置のパ ラメータとその組合せを表 2 に示す. 以下の説明では, 表中の standardの欄の組合せを基準形と呼び, Variation 欄に示した変更がある場合，そのことを明示し た。また，遊星歯車の個数が 3 個の場合を 3 遊星， 3 個 の遊星の内 1 個を取除いた場合を 2 遊星と略称する.

\section{3. 実験結果および考察}

$3 \cdot 1$ 太陽軸の横振動応答 基準形 ( 3 遊星)の実
表 1 歯車主要目

\begin{tabular}{|l|c|c|c|}
\hline & Sun gear & Planetary gear & $\begin{array}{l}\text { Internal } \\
\text { gear }\end{array}$ \\
\hline Tooth profile & \multicolumn{3}{|c|}{ Profile shifted spur gear } \\
\hline Tool $\begin{array}{l}\text { Tooth shape } \\
\text { Module } \\
\text { Pressure angle }\end{array}$ & \multicolumn{3}{|c|}{$\begin{array}{c}\text { Standard tooth } \\
1.5 \\
20^{*}\end{array}$} \\
\hline Tooth width & \multicolumn{3}{|c|}{$20 \mathrm{~mm}$} \\
\hline Number of teeth & 18 & 79 & 177 \\
\hline Standard PCD & $27 \mathrm{~mm}$ & $118.5 \mathrm{~mm}$ & $265.5 \mathrm{~mm}$ \\
\hline $\begin{array}{l}\text { Addendum moddifi- } \\
\text { cation coeficient }\end{array}$ & 0.5 & -0.5 & -0.98 \\
\hline JIS accuracy class & 3 & $2 \sim 3$ & $3 \sim 4$ \\
\hline $\begin{array}{l}\text { Decrement of teeth } \\
\text { thickness } \\
\text { (normal direction) }\end{array}$ & $62 \mu \mathrm{m}$ & $96 \mu \mathrm{m}$ & $185 \mu \mathrm{m}$ \\
\hline
\end{tabular}

表 2 実験装置パラメー夕の組合せ

\begin{tabular}{|c|c|c|c|c|}
\hline & \multirow{2}{*}{$\begin{array}{l}\text { Planets } \\
\text { (Nunber) }\end{array}$} & \multirow{2}{*}{$\begin{array}{c}\text { Additional } \\
\text { eass }\end{array}$} & \multicolumn{2}{|c|}{ Shaft coupling } \\
\hline & & & Motor side & Dynano. side \\
\hline Standard & Three & No & $\begin{array}{l}\text { Diaphrage type } \\
\text { (High torsional } \\
\text { stiffness) }\end{array}$ & Spline type \\
\hline Variation & Two & Attached & $\begin{array}{l}\text { Diaphragu type } \\
\text { (Low tortional } \\
\text { stiffness) or } \\
\text { Rubber type }\end{array}$ & Diaphrasn type \\
\hline
\end{tabular}

験装置を負荷トルク一定 $(1,2 ， 3 \mathrm{Nm})$ で増速運転し た場合の, 太陽軸横振動の鉛直方向振動応答を図 3 （a ）に，2 遊星の装置で同様の運転をした場合の水平 方向振動応答を図 3 (b) に示す。図より,太陽軸の横 振動は特定回転速度で急に大きくなり，その後，3遊 星の場合はほほ一定，2遊星の場合は次第に小さくな る傾向を示すことがわかる。この振幅の大きな振動を 異常振動と呼ぶ. 異常振動発生回転速度は, 負荷トル クが大きくなるにつれ顕著に高くなる.図 $3(\mathrm{a})$, （b）の振動応答(負荷トルク $2 \mathrm{Nm}$ )の $200 \mathrm{rpm}$ ごとの 回転速度における周波数分析結果を図 4 (a)，(b)に それぞれ示す.図 4 (a), (b) の横軸が振動数, 縦軸が

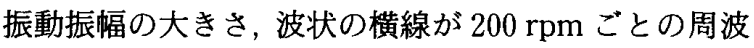
数分析結果である. 図中の $f s$ および $f i$ はそれぞれ太 陽軸および内歯車軸の回転速度に等しい振動数であ る. 異常振動発生時 [図 4 (a) では $7800 \mathrm{rpm}$ 以上, 図 4 (b)では $6000 \mathrm{rpm}$ 以上]では, $3 f i$ の成分が顥著で あることがわかる. 図 4 (b)の $33.5 \mathrm{~Hz}$ の綐線は, 2000 ～ $000 \mathrm{rpm}$ で常に見られる振動成分で，系のなん らかの固有振動数と思われる. 図 4(b)からは, 異常 振動は $3 f i$ の振動数をもつ加振力(この加振力は, 遊 星歯車が $120^{\circ}$ 間隔に取付けられていることに起因す ると思われる)と軸系のある固有振動数 $33.5 \mathrm{~Hz}$ によ る共振のように思われる。しかしながら, 図4(a)の 


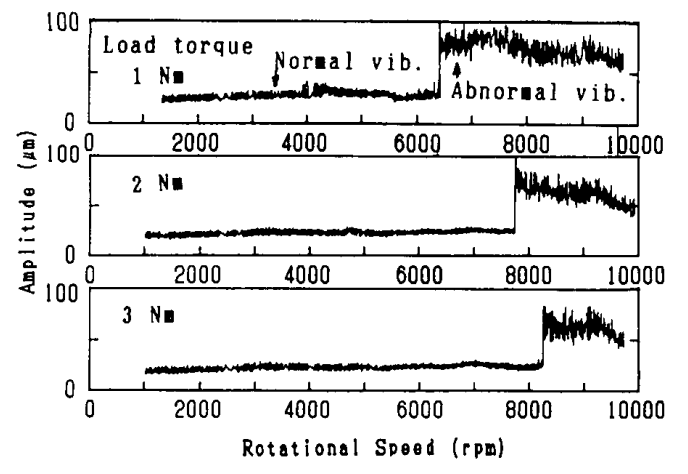

(a) 3 遊星 (垂直方向)

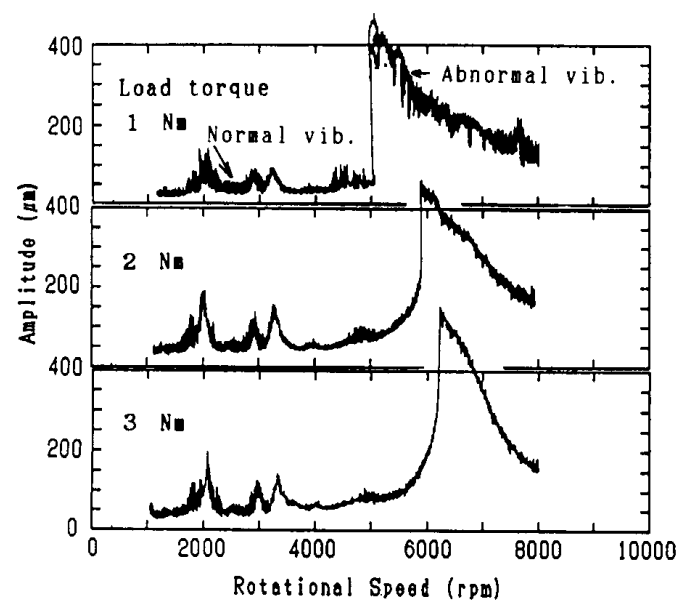

(b) 2 遊星(水平方向)

図 3 太陽軸横振動応答

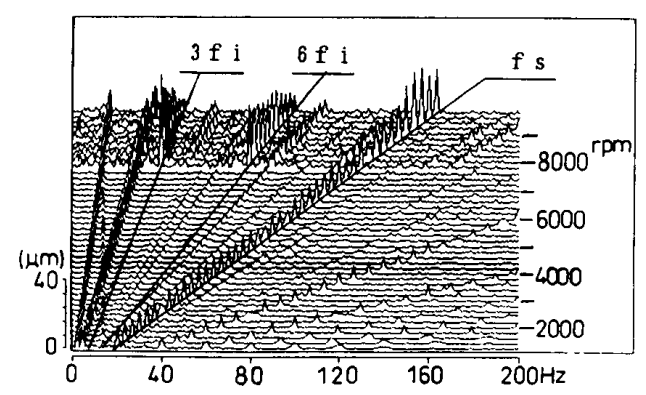

(a) 3 遊星 (垂直方向, $2 \mathrm{Nm}$ )

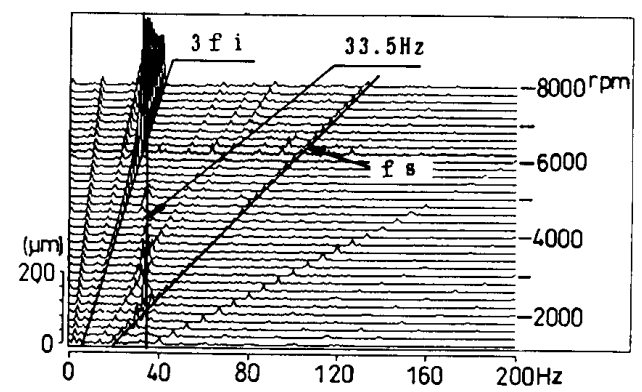

（b） 2 遊星 (水平方向, $2 \mathrm{Nm}$ )

$f i$ : Rotational speed of internal gear $f s$ : Rotational speed of sun gear

図 4 太陽軸横振動周波数分析
3 遊星の場合ではこうした固有振動数成分は見あたら ない. 図 5 ( a )，(b) は，それぞれ 3 遊星，2遊星の装 置を一定回転速度で運転し，負荷トルクを増減させた 場合の太陽軸横振動の応答を示す。両応答より，負荷 トルクが大きくなると異常振動は消滅し，振動振幅は強 いトルク依存性とヒステリシス性を示すことがわかる。 $3 \cdot 2$ 太陽軸のセルフセンタリング 経路と振動軌跡 太陽軸は, 遊星歯車との間にガ夕をもつため, 非回転 時には重力によりガタの範囲の最下点に位置するが, トルクが加わると上方の平衡位置 (センタリング位置) へ移動する。これをセンタリング過程という。ここで は基準形の 3 遊星， 2 遊星それぞれの装置を用いて， ガタによる太陽軸中心の可動範囲，およびダイナモ軸 を固定し，モータ軸に静トルクを加えた場合の太陽軸 中心のセルフセンタリング経路を実測した．得られた 結果を図6(a), (b)に示す。

3 遊星 [図 6(a-1)］の場合, 可動範囲は一辺 300〜 $500 \mu \mathrm{m}$ の六角形で, 図示の方向にトルクを加えると, 太陽軸中心は初期位置によって異なる折れ線に沿って 上昇し, 約 $0.4 \mathrm{Nm}$ ほどのトルクでセンタリング位置 に達する．それ以上のトルクを加えてもセンタリング 位置は移動しない．この領域では三つの遊星歯車は, 太陽雷車としっかりかみ合っているものと思われる。

2 遊星［図 $6(\mathrm{~b}-1)]$ の場合, 可動範囲は, 取除いた No. 2 遊星の側に開いた台形となり，トルクが作用し なければ太陽軸中心は常に最下点に位置する．図示の 方向に静トルクを加えると, 図 $6(\mathrm{~b}-1)$ に示す唯一の 折れ線経路に沿ってセンタリング位置に達する.トル クを $1,3,5,7 \mathrm{Nm}$ と増加させると, センタリング位 置は，遊星歯車支持ピンの弾性のためガ夕の範囲を越 えて移動する。

これらの装置を負荷運転し, 太陽軸の振動が小さい
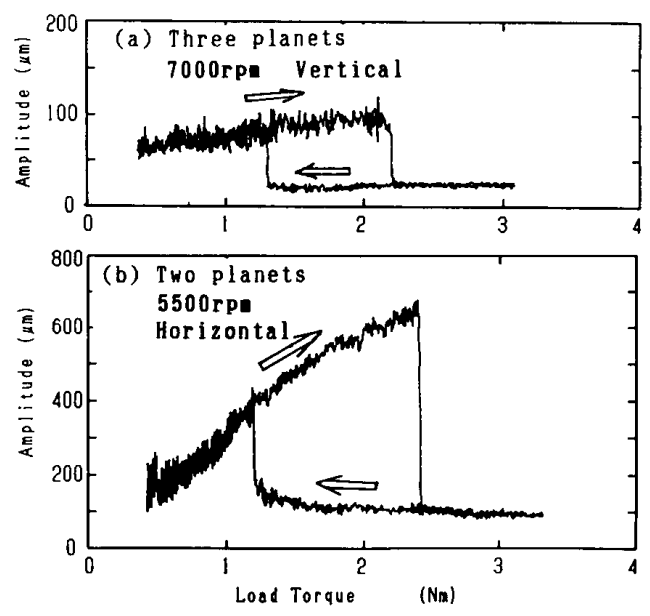

図 5 トルク変化に対する太陽軸横振動応答 


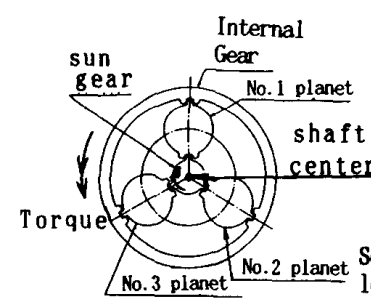

(a) 3 遊星

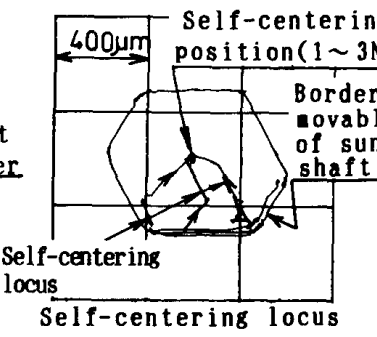

$(a-1)$

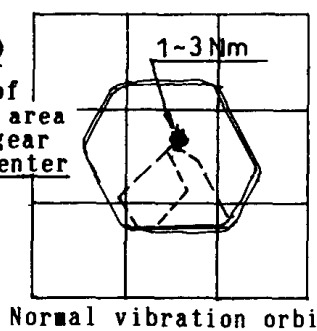

$(\mathrm{a}-2)$

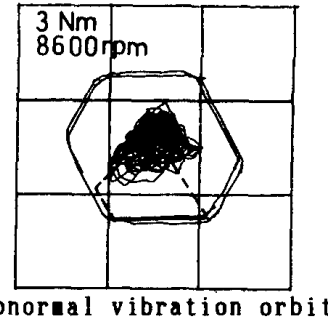

$(\mathrm{a}-3)$

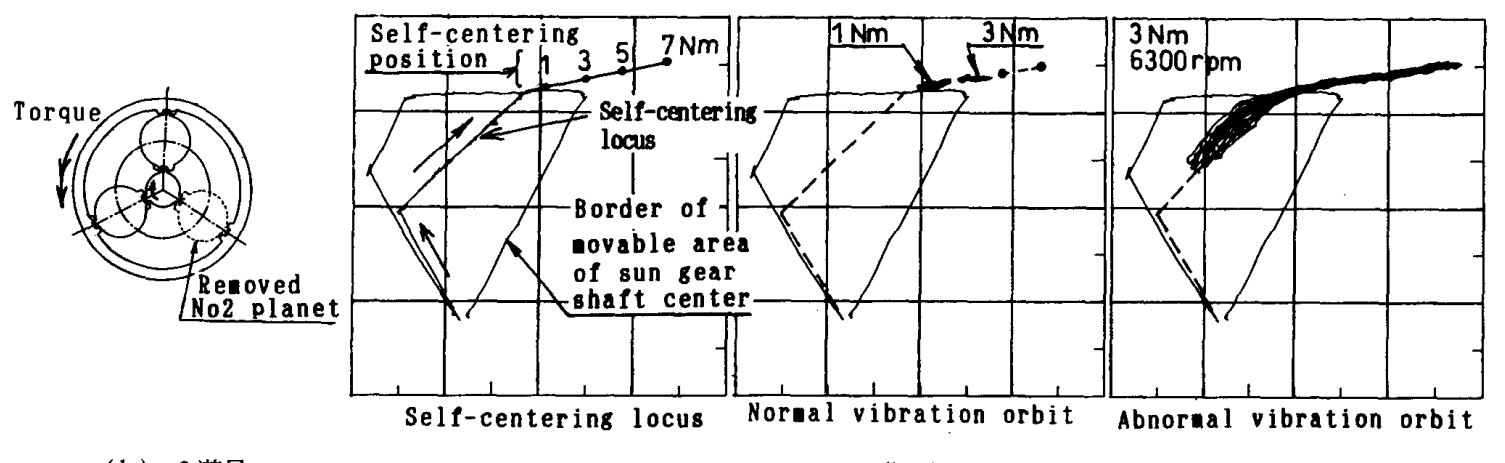

(b) 2 遊星

(b-1)

(b-2)

(b-3)

図 6 太陽軸の非回転時のセルフセンタリング経路および回転時の振動軌跡

正常振動の場合，および異常振動の場合の，軸心軌跡 を測定した。結果を図 $6(\mathrm{a}-2) ，(\mathrm{a}-3) ，(\mathrm{~b}-2) ，(\mathrm{~b}-3)$ に示す。陽軸中心は正常振動時には，セルフセンタ リング位置のまわりを小さく運動する，異常振動時に は，3遊星の場合, セルフセンタリング位置より下側 に広がる複雑な軌跡を描くが [図 $6(\mathrm{a}-3)] ， 2$ 遊星の 場合, 特定の方向に振動する軌跡を描き，その軌跡が セルフセンタリングの経路(破線)に極めてよく一致す ることがわかる $[$ 図 $6(\mathrm{~b}-3)]$. 図 $6(\mathrm{a}-3)$ で軌跡が複雑 なのは, 太陽軸の初期位置により無数のセルフセンタ リング経路があるためと考えられる.

以上より，太陽軸の異常振動は, 何らかの原因で太 陽歯車と遊星歯車の歯面が離れて，太陽軸が自重で下 方へ落下し, 再び歯面のかみ合いによってセルフセン タリング経路に沿って上方のセンタリング位置へ戻る ことの繰返しであると推測できる.

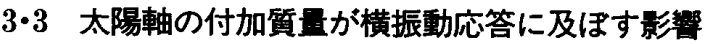

$3 ・ 1$ 節 [図 4 (b)の説明]で, 2 遊星の場合, 太陽軸の 異常振動は, $3 f i$ の加振力と系のある固有振動数の共 振によって生じるらしいと述べた。ここでは 2 遊星の 装置を用い, 太陽軸の質量が，この固有振動数や異常 振動発生回転速度に及ほす影響を調べた。すなわち， 太陽軸 $(1.2 \mathrm{~kg})$ のみの場合および太陽軸に $1.4 \mathrm{~kg} の$ 付加質量を取付けた場合の実験を行い，横振動応答図 7 (a)，(b)ならびに, 周波数分析結果図 7 (c), （d）を得た。図 7 (a)，（b)の $3 f i$ 成分をもつ異常振
動の発生回転速度 $5500 \mathrm{rpm}$ および図 7 (c), (d)の 固有振動数と思われる $32.5 \mathrm{~Hz}$ は, ともに太陽軸の付 加質量の影響を全く受けていないことがわかる。なお, 図 7 (b)の $4200 \mathrm{rpm}$ 付近のピークは, 4fi の成分の 加振力が $32.5 \mathrm{~Hz}$ と共振したためと思われる. 3 遊星 の場合も同様の実験を行っているが, 太陽軸の付加質 量は異常振動発生回転速度にほとんど影響を及ほさな い. 以上より, 太陽軸の異常振動は, 太陽軸単独で発生 するのではなく, 軸系のねじり振動などの他の要因に 関連して発生するものと考えられる。なお，本節の実 験は, 基準形を 2 遊星に,ダイナモ側軸継手をダイア フラム形に変更した装置を用いている。

\section{$3 \cdot 4$ モ一タ側軸継手のねじり岡性が横振動応答に} 及ほす影签こここでは基準形の装固で，モー夕側軸 継手のねじり剛性を変えて実験を行った。すなわち， ねじり剛性の異なる二つのダイアフラム形軸継手，お よびねじり剛性のかなり低いゴム継手を用いた場合に ついて, 負荷トルク $2 \mathrm{Nm}$ で增減速運転を行った。得 られた応答を図 8 (a)，（b)，(c)にそれぞれ示す.軸 継手のねじり剛性が低いと, 異常振動発生回転速度は 顕著に低下し, ゴム軸継手の場合, 異常振動は観察さ れなくなった.このことより,太陽軸の異常横振動は, 軸系のねじり振動と密接な関連があると考えられる。

\section{5 太陽軸横振动・軸系のねじり振动同時測定}

ここで太陽軸の横振動および軸系のねじり振動の同時 測定を行った. 基準形の 3 遊星および 2 遊星の場合 


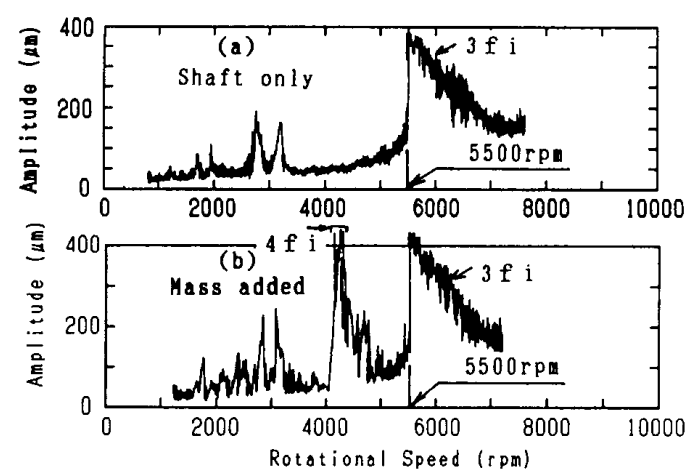

（a）横振動応答
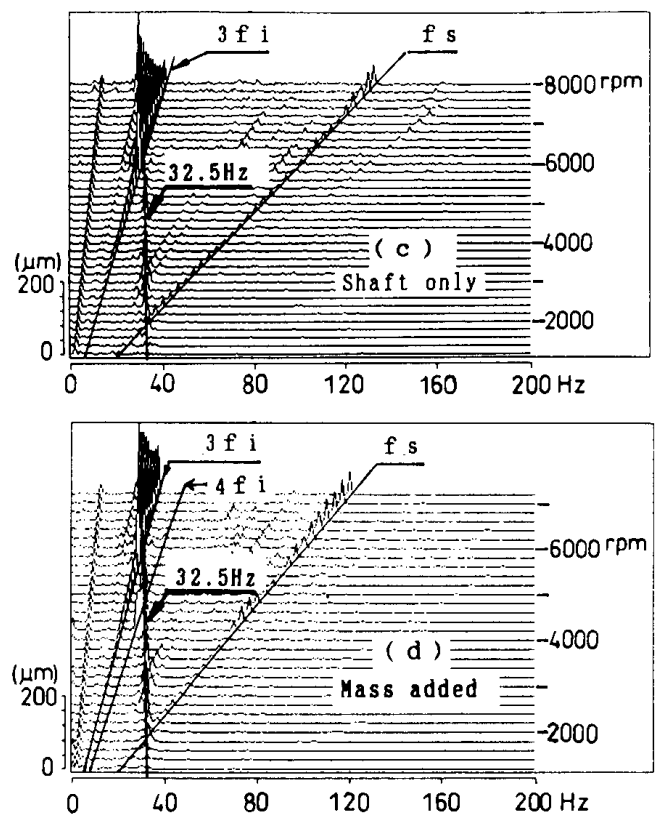

(b) 周波数分析結果

Two planets: 2 Na: Horizontal: Diaphragi coupling

図 7 太陽軸の負荷質量が横振動の応答および周波数分析 結果に及ほす影響

について負荷トルク $2 \mathrm{Nm}$ で増速運転を行った際の 応答を図 9 ( a )，（b)にそれぞれ示す. 3 遊星の場合 [図 9(a)] は $7700 \mathrm{rpm}$ で, 2 遊星の場合 [図 9 (b)] は $5900 \mathrm{rpm}$ で, 太陽軸横振動および軸系のねじり振 動の振幅が, 両者同時に顕著に大きくなっており,太 陽軸異常振動はねじり振動振幅が大きいときに発生し ていることがわかる.また，このときのねじり振動応 答の周波数分析結果が図 $10(\mathrm{a})$ ，(b)で，これより， 振幅が大きい場合のねじり振動は, $3 f i$ の振動数成分 が顕著であることがわかる。

$3 \cdot 6$ 打撃実験による系の固有振動数 基準形の 3 遊星および 2 遊星の装置を用いて, 非回転時におけ る, 軸系のねじりおよび太陽軸横振動の固有振動数を

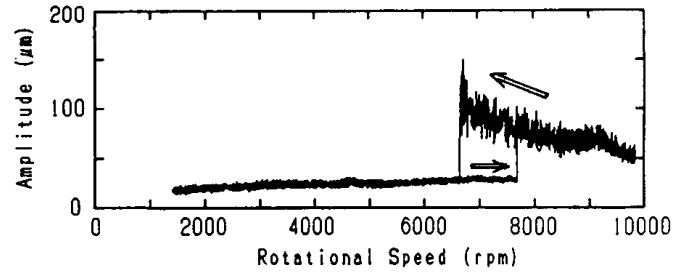

(a) No.1 ダイアフラム形軸継手 $(\mathrm{Kt}=2 \mathrm{kNm} / \mathrm{deg})$

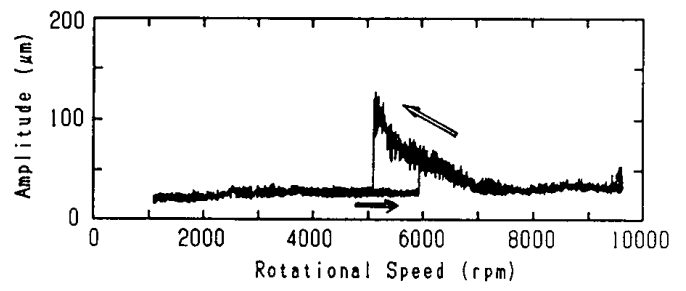

(b) No. 2 ダイアフラム形軸継手 $(\mathrm{Kt}=300 \mathrm{Nm} / \mathrm{deg})$

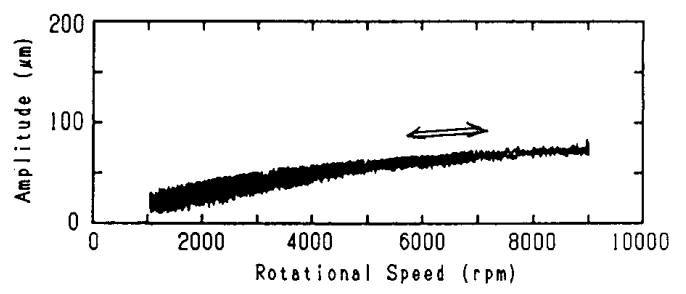

(c) ゴム継手 $(\mathrm{Kt}=2 \mathrm{Nm} / \mathrm{deg})$

図 8 モー夕側軸継手ねじり剛性が太陽軸横振動に及ぼす 影響 (3 遊星, $2 \mathrm{Nm}$, 垂直方向))

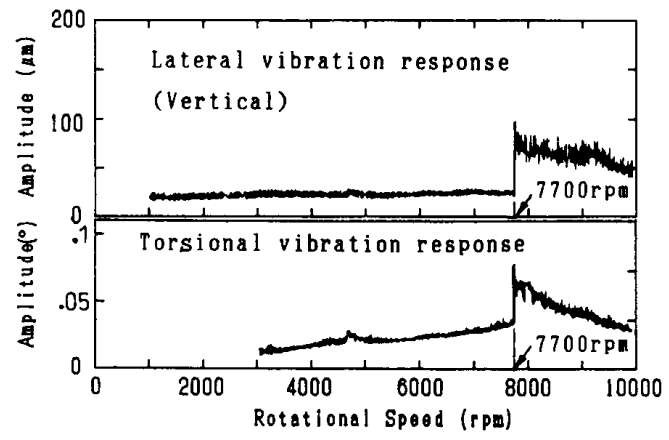

(a) 3 遊星

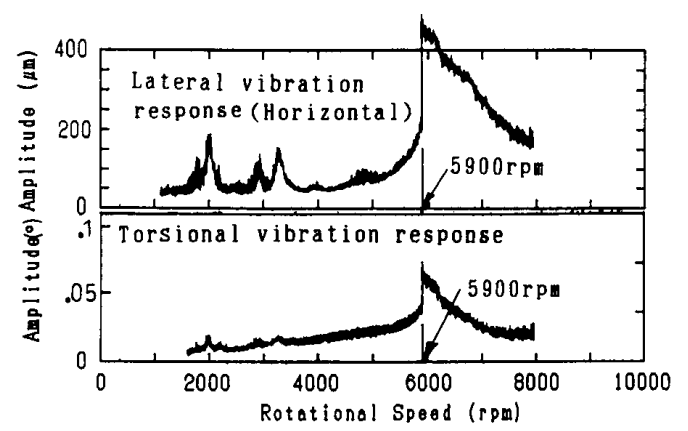

(b) 2 遊星

図 9 太陽軸横振動と内歯車軸ねじり振動応答比較 


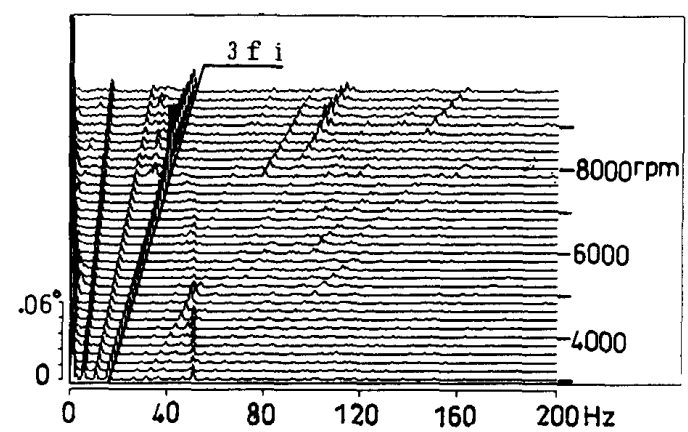

(a) 3 遊星 $(2 \mathrm{Nm})$

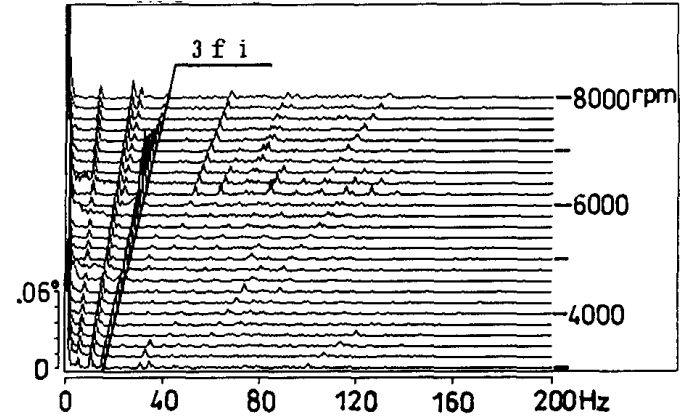

(b) 2 遊星 $(2 \mathrm{Nm})$

図 10 内歯車軸ねじり振動の周波数分析

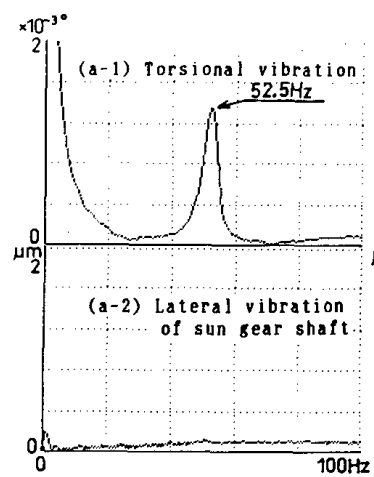

(a) 3 遊星

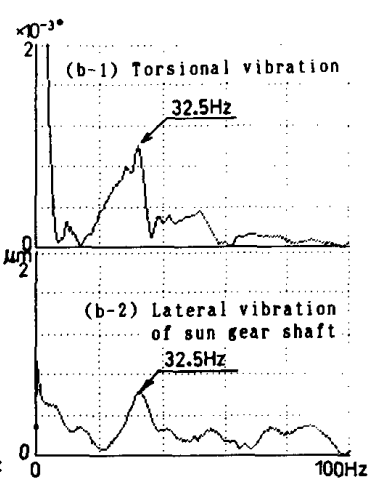

(b) 2 遊星
図 11 打拲時の振動波形の周波数分析結果

打撃実験により求めた。まず二つのばねばかりをモー 夕側, ダイナモ側の継手フランジ部に取付け, 軸系に 静トルクを加えてガタの影響をなくし，その後装置を 打撃した。得られた振動波形の周波数分析結果の一例 を図 11(a)，（b)に示す. 3 遊星の場合，ねじり振動 の固有振動数は $52.5 \mathrm{~Hz}$ [図 $11(\mathrm{a}-1)$ ] で, 横振動の固 有振動数は認められなかった [図 $11(\mathrm{a}-2)]$. 打撃個所 を変えて測定したが, 横振動の周波数分析結果には $100 \mathrm{~Hz}$ までの範囲では大きなピークはなかった。一 方, 2 遊星の場合，ねじり振動と横振動の固有振動数 は $32.5 \mathrm{~Hz}$ と一致している [図 $11(\mathrm{~b}-1),(\mathrm{b}-2)]$.こう
表 3 固有振動数と異常横振動発生回転速度

\begin{tabular}{|c|l|c|}
\hline & $\begin{array}{l}\text { Natural } \\
\text { torsional } \\
\text { frequency fo }\end{array}$ & $\begin{array}{c}\text { Onset speed of } \\
\text { abnornal vib. }\end{array}$ \\
\hline 3 Planets & $52.5 \mathrm{~Hz}$ & $\begin{array}{c}7700 \mathrm{rpa} \\
(3 \mathrm{fi}=39.2 \mathrm{~Hz})\end{array}$ \\
\hline 2 Planets & $32.5 \mathrm{~Hz}$ & $\begin{array}{c}5900 \mathrm{rpa} \\
(3 \mathrm{fi}=30.0 \mathrm{~Hz})\end{array}$ \\
\hline
\end{tabular}

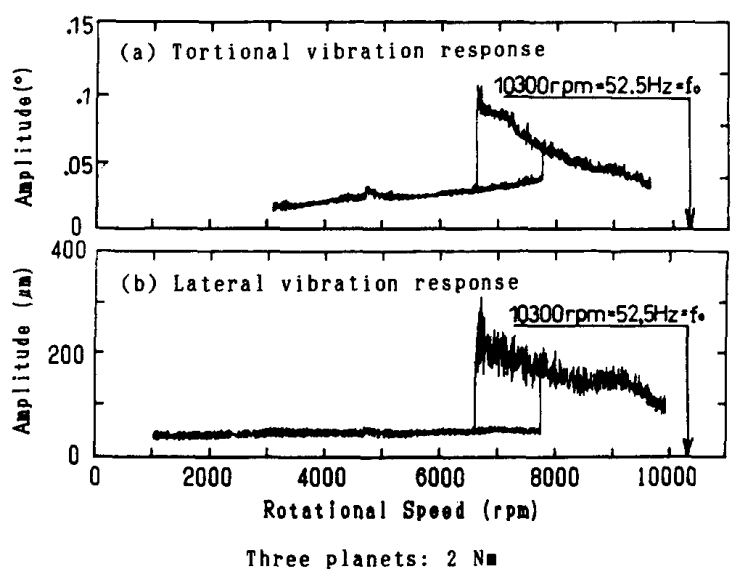

図 12 回転速度增減速時の振動応答

したことは, トルク付加状態では, 軸系のねじり振動 と太陽軸の横振動が， 3 遊星の場合は連成せず，2遊 星の場合は連成することを意味しており，図40低速 域で固有振動数成分が，3遊星の場合認められず，2 遊星の場合認められたことに対応している。なおこ れらの固有振動数の值は加えるトルクを変えても変化 しなかった．モー夕側のダイアフラム形軸継手を，ね じり剛性の低いもの［図 8 (b) と同じ] に変えたとき, 3 遊星の場合のねじり固有振動数は $52.5 \mathrm{~Hz}$ から 35 $\mathrm{H} z$ に低下した。

\section{$3 \cdot 7$ 振動応答と固有振勳数の関係および異常振動}

発生機棈 これまでに得られた基準形の 3 遊星と 2 遊星の場合のねじり固有振動数と異常横振動発生回転 速度を表 3 にまとめて示す，表より，固有振動数は異 常横振動発生回転速度よりかなり高いことがわかる. ここで両者の関連について考察する.図 12 に, 表 3 の 3 遊星の場合のねじりと横振動の応答(減速時の応答 も含む）を示す. あわせて同図中に固有振動数 $f_{0}=52.5$ $\mathrm{Hz}$ に対応する回転速度を示した. 図より，二つの応答 はジャンプ現象を伴う非線形系の共振の特幑を示して おり，非線形の原因は遊星霜車装置の歯車のバックラ ッシであると考えられる，共振現象を論ずるために， 振動の主成分である 3 fi の振動数成分に着目し, 図 12 の応答から $3 f i$ 成分の振幅を抽出してプロットしたの 


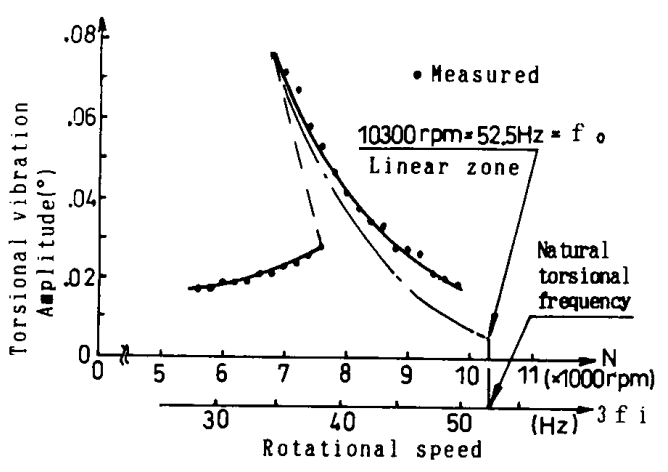

(a) ねじり振動応答

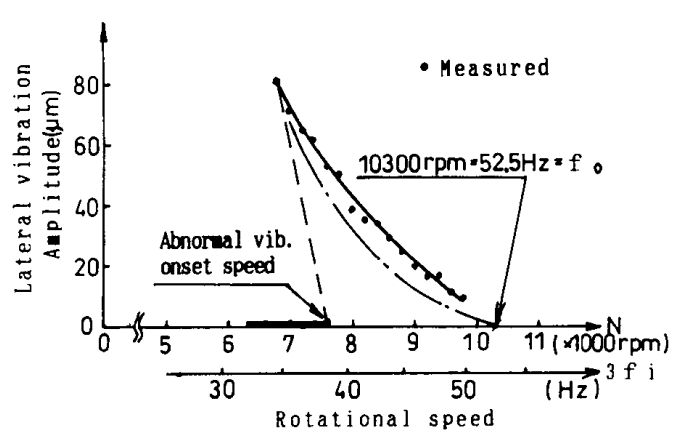

（b）太陽軸横振動応答

Three planets: $2 \mathrm{Nm}$

図 $133 f i$ 振動成分の応答と固有振動数の関係

が図 13(a)，(b)である。これらの図は実際には，図 10 (a)，図 4 (a) 等の周波数分析結果の $3 f i$ 成分の大 きさをプロットしたものである．図中の横軸は，太陽 軸回転速度 $N(\mathrm{rpm})$ のほかに, $3 f i(\mathrm{~Hz})[=3 \mathrm{~N} /(60 \times$ 9.82)］を目盛ってある。実線は・印を滑らかに連ねた 応答曲線，破線はジャンプ現象で観測できない応答曲 線を模式的に示している. $f_{0}=52.5 \mathrm{~Hz}$ はガタがない場 合のねじりの固有振動数であり，応答のピークは 35 $\mathrm{Hz}$ 付近でかなり低い.しかしながら，これをガタ系の 非線形共振と考えると, 文献 $(1) \sim(3)$ 等により, 固 有振動数と振幅の関係を示す背骨曲線は, 不明な点も あるが模式的に図 13(a)，（b )の一点鎖線のように書 ける。これにより，ガタがない場合のねじり固有振動 数と異常振動発生回転速度の関係がかなり明らかにな ったと思われる。図13(a)の杖り振動応答では，振 幅が小さく, 各歯車がしっかりかみ合っている間は系 は線形で，共振時に振幅が大きく，歯面分離を生じる と系はガ夕をもつ非線形となる.図 13(b)の太陽軸の 横振動応答では，歯面分離が生じない範囲では，太陽 軸はセンタリング位置でほとんど動かない。しかし， ねじり共振時歯面分離が生じると，太陽軸はねじり振 動と同様なガ夕非線形性を示す。その結果，太陽軸横 振動の背骨曲線は, ねじり振動のそれの線形部分を除

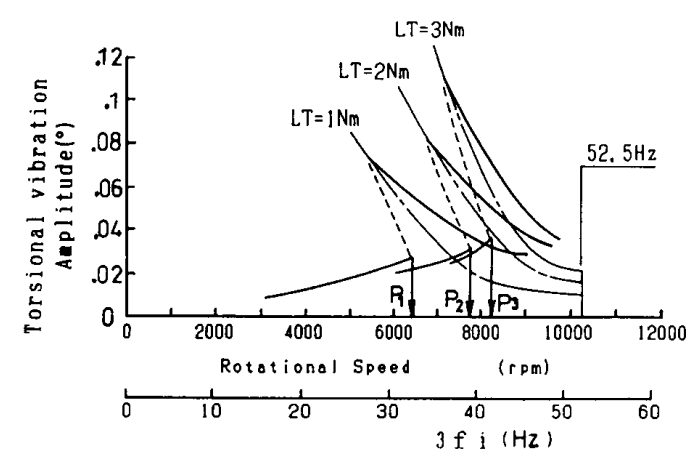

Three planets

図 14 ねじり振動応答 ( $3 f i$ 成分) のトルク依存性

いたものになると考えられる，異常振動時の太陽軸の 挙動は, $3 \cdot 2$ 節末尾に述べたとおりである. 図 12,13 では，3 遊星の場合を示したが，2 遊星の場合もほぼ 同様に説明できる。

以上より，ねじり振動系の固有振動数を低くすれば, 太陽軸の異常振動発生回転速度が低くなること,太陽 軸の質量はねじり固有振動数をほとんど変化させず, その結果異常振動発生回転速度にほとんど影響を及ほ さないこと，ねじり振動と太陽軸横振動の応答曲線は ほとんど同じになること等が説明できる。こうしたこ とから，本異常振動を低隇又は除去するには，軸系の ねじり共振を運転範囲外にしたり,ゴム継手を用いて ねじりの隇衰を高める[図 $8(\mathrm{c})$ 参照]等が考えられる。 3.8 異常横振動のトルク依存性 太陽軸異常横 振動の発生回転速度および振幅は強いトルク依存性を 示すことは既に述べた(図 3,5 参照)。ここでは，その 理由について考察する。異常横振動は, ねじり振動と 同じ応答を示すので, ねじり振動で考察を行う. 図 13（a）に，負荷トルク 1 および $3 \mathrm{Nm}$ の場合を追加し た図 14 を作成した. 図中の一点鎖線，および破線の意 味は図 13 の場合と同じである. 図 14 より, 負荷トル クが 1, 2, $3 \mathrm{Nm}$ と大きくなるにつれ, 異常振動発生 回転速度が $P_{1}, P_{2}, P_{3}$ と高くなっていること，また異 常振動振幅が大きくなっていることがわかる.このこ とは, 負荷トルクの增加とともに, 背骨曲線が線形系 のそれ( $52.5 \mathrm{~Hz}$ を通る垂直線)に近づくと考えると理 解しやすい。すなわち，背骨曲線は線形系の垂直部分 が長くなり，非線形の湾曲部分も立上がり全体として 線形系のそれに近づく。この理由は，ねじり振動の振 幅が同じ場合, 負荷トルクが大きいほど, 歯車の歯面 分離の割合が少なくなり，より線形系に近い挙動を示 すことによると思われる。図 14 は 3 遊星の場合を示し たが，2遊星の場合もほほ同样である。 


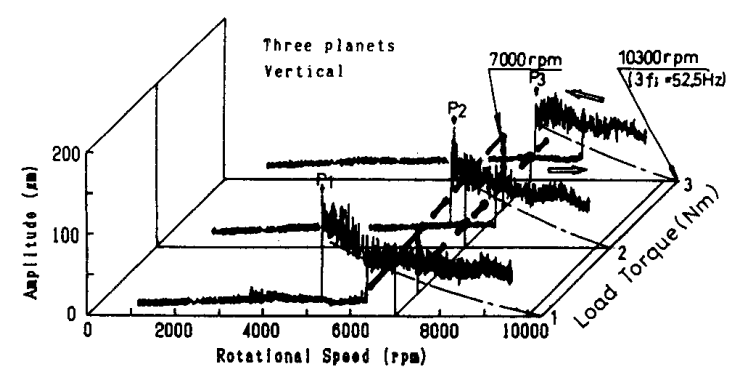

図 15 太陽軸横振動応答の三次元表示

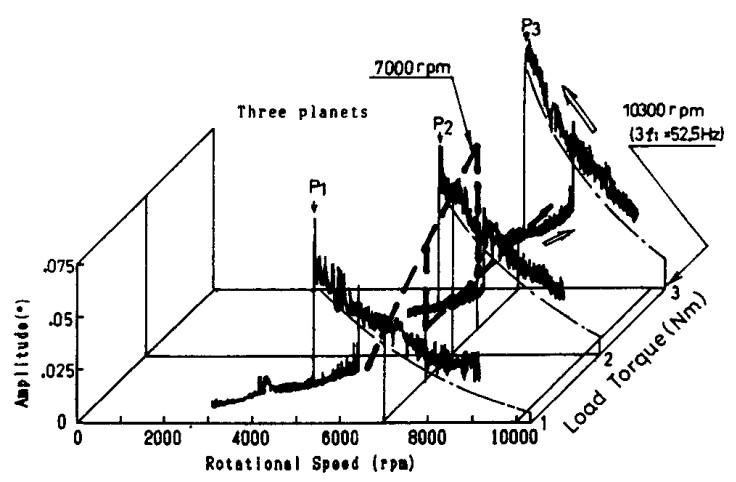

図 16 ねじり振動応答の三次元表示

図 15 および 16 は，負荷トルクが $1,2,3 \mathrm{Nm}$ の場 合の, 横振動およびねじり振動応答を, トルク軸を斜 め方向の軸として，三次元的に示したものである. 図 15,16 の三つの応答曲線と回転速度一定の平面との交 点を結ぶ曲線は，それぞれ図 5 (a)および図 17 で示 したトルクを横軸にとった振動応答となる. 図 5 (a), 図 17 において, 負荷トルクにより, 振動振幅が変化す るのは，図 14 で述べたようにトルクが大きいほど, 背 骨曲線 (一点鎖線) と応答曲線が立上がり，振幅の跳故 点が高速側へ移動するためである。

\section{4. 結言}

モータ, 遊星歯車増速機, ダイナモメータから成る 回転軸系に発生する太陽軸の異常振動について, その 特徵およびねじり振動との関連に着目した実験を行い 以下の結論を得た。

（1）本装置を一定の軽負荷トルクで増速運転する と, 太陽軸は特定回転速度以上で, 内歯車回転速度の 3 倍の振動数をもつ異常横振動を発生する. 振動発生 回転速度は負荷トルクの増加とともに高くなる. 回転 速度一定で運転した場合, 振動振幅は負荷トルクの增 加とともに大きくなりその後急に小さくなる。これら 二つの応答はいずれも増隇速時，およびトルク負荷除 荷時にヒステリシス特性を示す。

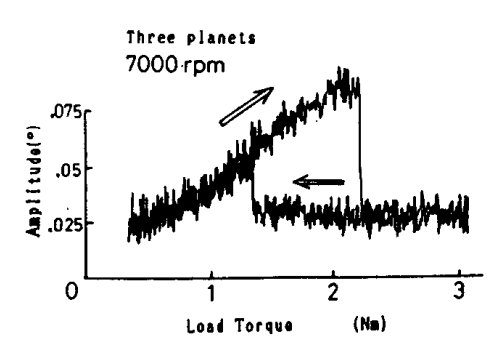

図 17 トルク変化に対するねじり振動応答

（2） 2 遊星の場合, 太陽軸の異常振動軌跡はセル フセンタリング経路にかなりょく一致した。このこと は, 負荷トルクが瞬間的に零となるときに, 異常振動 が生じることを意味する。

（3）異常振動発生回転速度およびこれに関連する 固有振動数は太陽軸質量の影響をほとんど受けず，モ 一夕側軸継手のねじり剛性の影響を顥著に受ける。モ 一夕側軸継手をゴムに変えると異常振動は発生しなく なった.

（4）軸系のねじり振動と太陽軸横振動の応答は, 同一回転速度で顕著なピークを生じ, その振動数は内 歯車回転速度の 3 倍であった。

（5）静止時，ガ夕をなくした回転軸系のねじりお よび横振動の固有振動数を打撃実験により測定した. この値と増減速時の応答曲線の関連および推定された 背骨曲線の形状より，本異常振動はガ夕をもつ非線形 系の共振であると考元られる.

（6）太陽軸の異常振動は, ガ夕をもつねじり振動 系が共振時に歯面分離を生じ，太陽軸は重力によって 落下, その後新たな歯面のかみあいによってセルフセ ンタリング位置へ戻ることの絽返しとして理解できる.

（7）異常横振動の発生回転速度および振幅が負荷 トルク依存性をもつのは, 負荷トルクが大きいほど, 歯面分離が生じにくくなり，ねじり振動系の背骨曲線 および応答曲線が立上がり，線形系のそれに近づくた めである.

本研究を行うにあたり，実験等精力的に行ってくれ た, 本学大学院学生 中村洋二君, 大津崇義君に感謝 の意を表す。

\section{文献}

（1）ミトロポリスキー,ユー、ア., ほか 1 名, 益子訳, 非線形振 動論, (1965), 219, 共立出版.

（2）前沢, 機論, 26-167 (1960), 884 .

(3) 金光, 機論, 51-464, C (1985), 773 .

（4）矢鍋・中村・吉野, 遊星歯車装置太陽軸のセルフセンタリ ングと異常振動, 機講論, No. 920-55, B (1992-7), 598. 